\title{
Freeze-Etching Images of Capillary Endothelial Pores in the Liver, Thyroid and Adrenal of the Mouse*
}

\author{
Kazunori Ishimura, Hisao Okamoto \\ and \\ Hisao Fujita
}

Received November 5, 1977

\begin{abstract}
Summary. The capillary endothelial pores of perfusion-fixed and immersion-fixed liver, thyroid and adrenal of mice were observed using freeze-etching preparations. In liver sinusoids, endothelial pores are heterogeneous in size and range from 50-100 $\mathrm{nm}$. When the pores are classified into three types according to their size, small pores up to $100 \mathrm{~nm}$ in diameter represent $69.8 \%$, intermediate pores measuring $100-500 \mathrm{~nm} 27.6 \%$ and large pores exceeding $500 \mathrm{~nm} 2.6 \%$ of all pores in number. The endothelial pores of the thyroid blood capillaries are fairly homogeneous in size $(70-90 \mathrm{~nm})$, corresponding to the small type pores in the liver. In both adrenal cortex and medulla, the capillary endothelial pores measure 40-50 $\mathrm{nm}$ in diameter, showing small and intermediate types. In the adrenal cortex the former occupy $80.6 \%$ of all pores and the latter $19.4 \%$. No larger type pores are recognized in the adrenal gland. These findings are not affected by different fixation methods, either perfusion or immersion.
\end{abstract}

As is well known, blood capillaries are classified into continuous and fenestrated types. The latter type is seen in endocrine glands, several exocrine glands, renal glomeruli and intestinal villi and characterized by the presence of numerous fenestrations or pores.

The freeze-etching method has the advantage of revealing a wide area of the membranes and is very useful for the study of the endothelial structure. Fenestrated capillaries of several organs have been examined using this method by FRIEDERICI (1968, 1969), Maul (1971), Simionescu et al. (1974), Fujita et al. (1975), Ishimura et al. (1976) and Yамамото et al. (1976).

The present authors observed the freeze-etching images of blood capillaries in the liver, thyroid and adrenal gland of mice and noticed that the fenestrations of the capillaries morphologically differed among these organs.

\section{Materials and Methods}

The liver, thyroid and adrenal cortex from male mice 1-4 months of age were perfusion-fixed through the left ventricle with $1.5 \%$ glutaraldehyde in $0.067 \mathrm{M}$ cacodylate buffer, pH 7.4 containing 1\% sucrose (SMith and FARQuHAR, 1966). After perfusion, the organs were removed and cut into small pieces. These tissue pieces were transferred to the same fixative for subsequent immersion fixation.

For comparison, small blocks of these organs from other mice were immersionfixed in the same fixative mentioned above and in $2 \%$ glutaraldehyde buffered at $\mathrm{pH}$

* This study was supported by a research grant from the Japan Educational Ministry. 


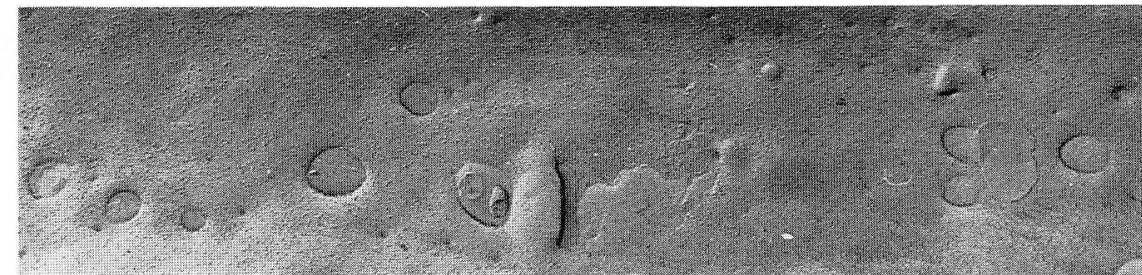

1

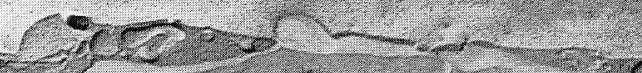

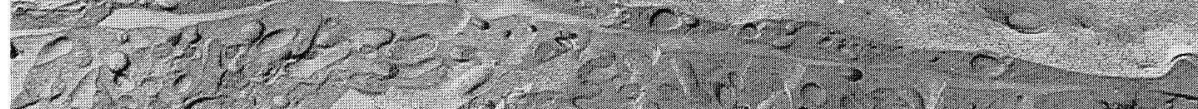

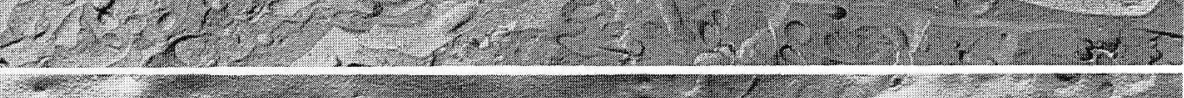

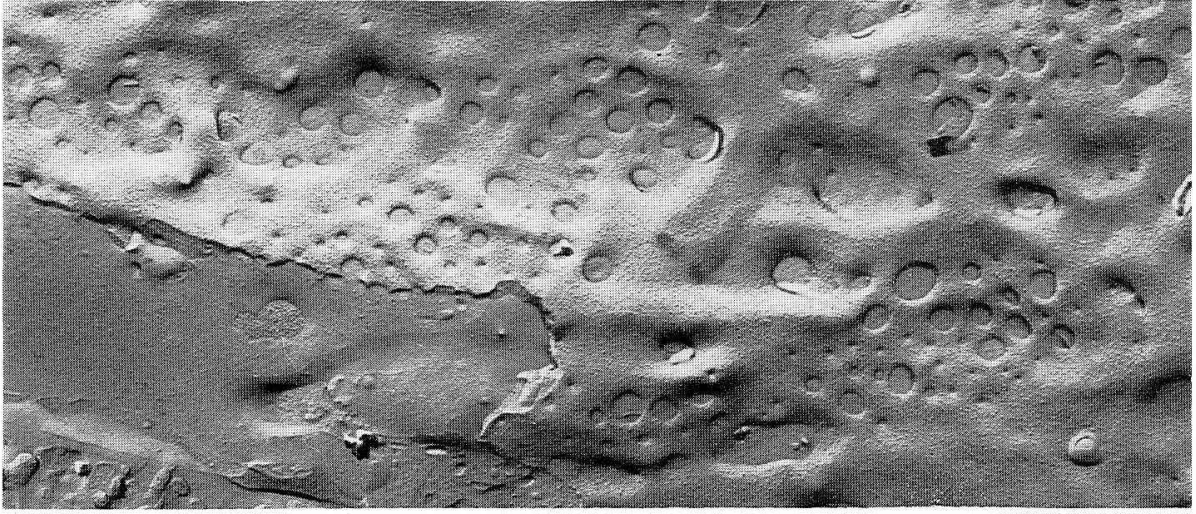

2

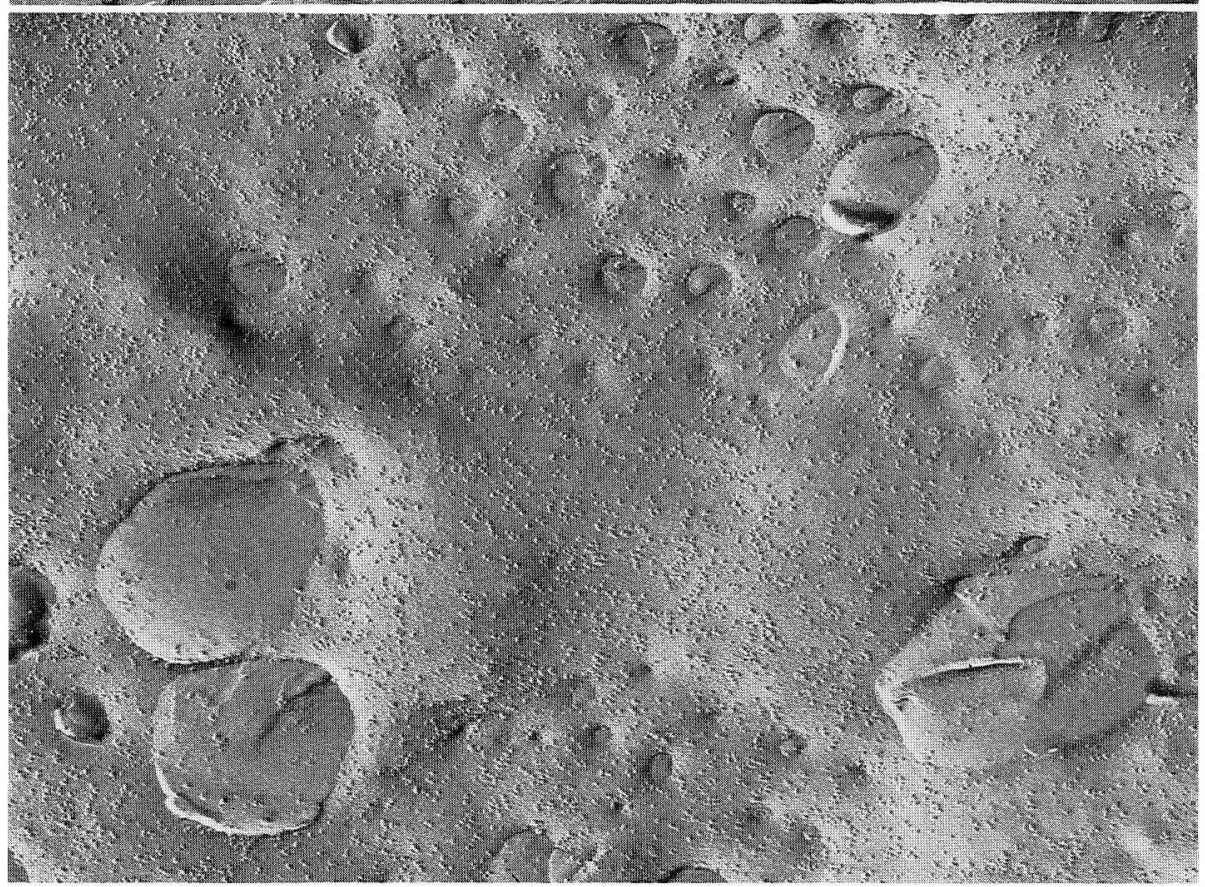

Fig. 1-3. Legends in opposite page. 
7.4 with Millonig's phosphate for 4-24 hrs. After fixation, the tissues were soaked in $30-40 \%$ glycerol solution for $4-12$ hrs and rapidly frozen in freon 22 cooled with liquid nitrogen.

The replicas were made in a JEE- $4 \mathrm{C}$ type freeze-etching apparatus and examined in a Hitachi HU-11D type electron microscope.

\section{Observations}

\section{Liver:}

On the plasma membrane of the liver sinusoid endothelium numerous round or oval pores (fenestrations) are observed (Fig. 1-3). These pores are often gathered in groups separated by the flat area devoid of pores. The population density of the pores is $15.3 \pm 2.4 / \mathrm{\mu m}^{2}$ in the crowded area. The diameter of most pores ranges from

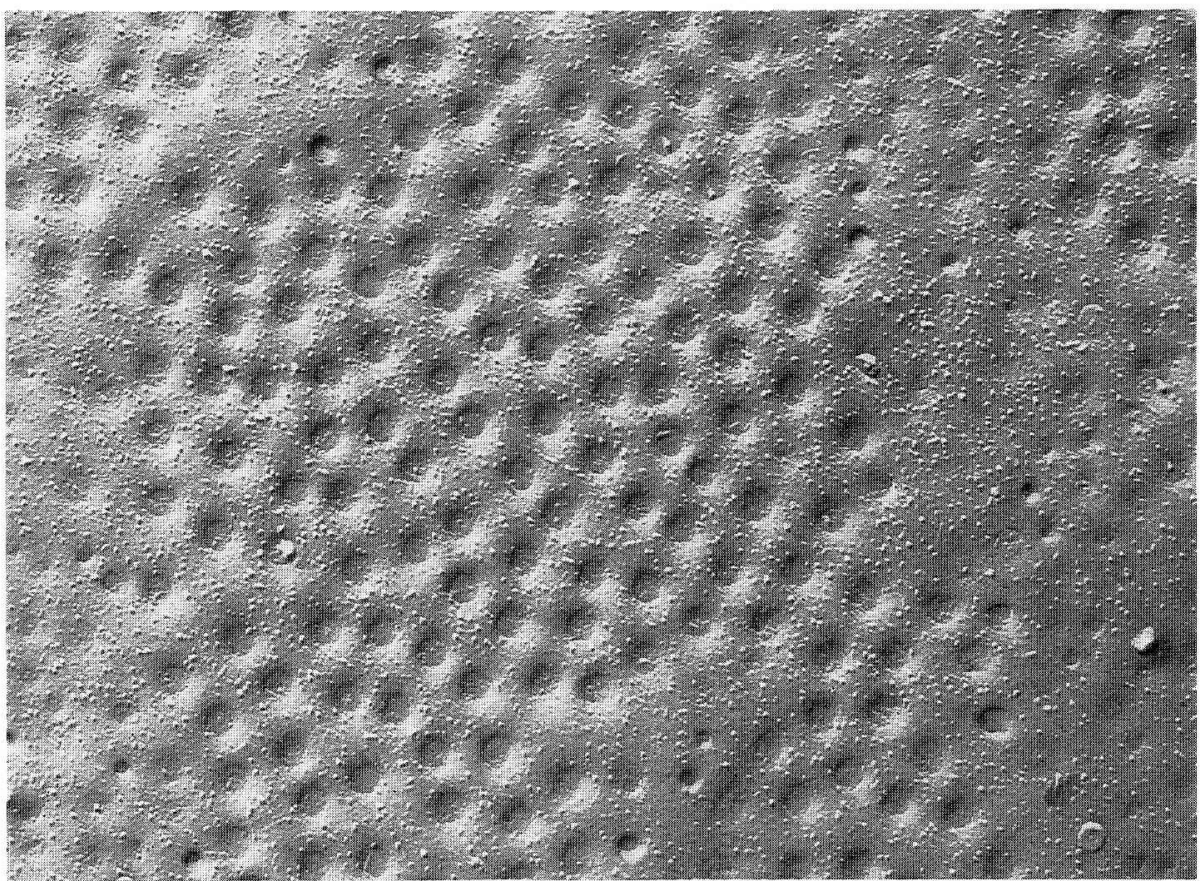

Fig. 4. Endothelium of blood capillary in thyroid gland of mouse. A PF of the endothelial plasma membrane of the tissue front. Numerous pores corresponding to the small type pores in the liver are densely distributed. $\times 42,000$

Fig. 1. Liver sinusoidal endothelium of mouse. The fracture reveals a PF of the endothelial plasma membrane of the blood front. Several intermediate type pores are scattered. $\times 16,000$

Fig. 2. Liver sinusoidal endothelium of mouse. The fracture reveals a PF of the endothelial plasma membrane of the tissue front. Numerous small and intermediate type pores are intermingled and gathered in clusters. $\times 14,000$

Fig 3. Liver sinusoidal endothelium of mouse. A PF of the endothelial plasma membrane of the tissue front is shown. A cluster composed of several small and intermediate type pores is seen. Three large type pores are also seen. $\times 42,000$ 
50 to $1,000 \mathrm{~nm}$ but none of them are larger than $2 \mu \mathrm{m}$. The pores are conventionally classified into three types according to their size, and their relative frequency is calculated. The small type pores not exceeding $100 \mathrm{~nm}$ correspond to $69.8 \%$ of all the pores in number, the intermediate type pores $100-500 \mathrm{~nm} 27.6 \%$, and the large type pores larger than $500 \mathrm{~nm} 2.6 \%$.

\section{Thyroid}

The endothelial pores of the thyroid blood capillaries are round in shape and measure $70-90 \mathrm{~nm}$ in diameter (Fig. 4). They all correspond to the small type pores in the liver and are distributed in clusters; the population density is $29.1 \pm 3.7 / \mu \mathrm{m}^{2}$ in the cluster. The flat or prominent zones devoid of pores and separating pore clusters are narrower than the corresponding structures in the liver sinusoid.

\section{Adrenal}

In both the adrenal cortex and medulla, the capillary endothelium possesses numerous pores. The pores are $50-400 \mathrm{~nm}$ in diameter and distributed in clusters (Fig. 5). Some of them correspond in size to the small type, while others to the intermediate one in the liver. No large type pores are found in the adrenal gland. The percentage in number of the small type pores is $80.6 \%$ while the intermediate ones $19.4 \%$ of all pores in the adrenal cortex; the population density of the pores of the cortex is $34.8 \pm 2.8 / \mu \mathrm{m}^{2}$ in the crowded area. In both the adrenal cortex and medulla,

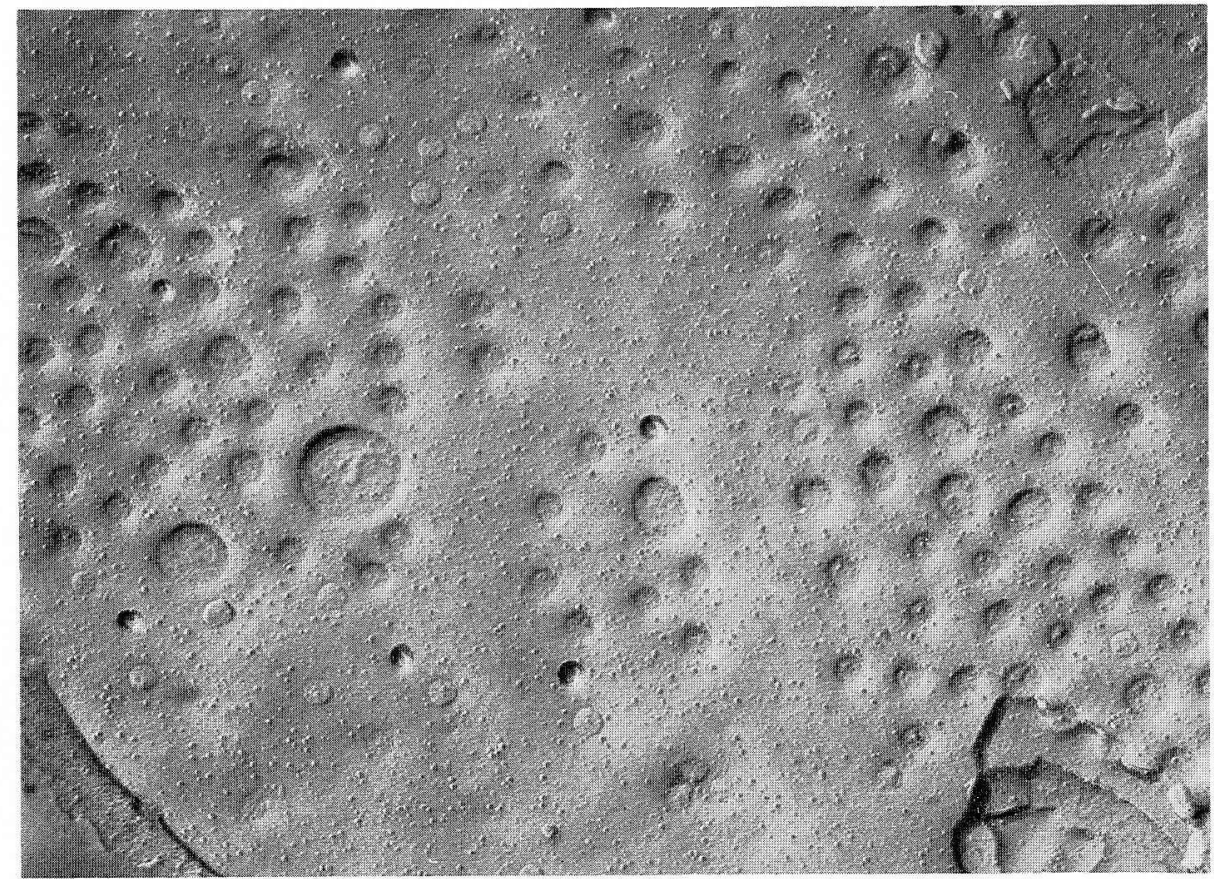

Fig. 5. Capillary endothelium in adrenal cortex of mouse. A PF of the endothelial plasma membrane of the tissue front. Several clusters of pores are observed. Some pores correspond to the small type in the liver and others to the intermediate type. $\times 42,000$ 
Table 1. Population density and diameter of capillary endothelial pores in liver, thyroid and adrenal cortex of mice

\begin{tabular}{lcl}
\hline & $\begin{array}{c}\text { Population density of } \\
\text { pores in crowded area } \\
\left(/ \mu \mathrm{m}^{2}\right)\end{array}$ & $\begin{array}{c}\text { Diameter of pores } \\
(\mathrm{nm})\end{array}$ \\
\hline Liver & $15.3 \pm 2.4$ & $50-1000$ \\
Thyroid & $29.1 \pm 3.6$ & $70-90$ \\
Adrenal cortex & $34.8 \pm 2.8$ & $50-400$ \\
\hline
\end{tabular}

the flat zones between the pored areas are wider than those in the thyroid capillary endothelium and are narrower than in the liver sinusoid.

These findings are not affected by the different fixation methods, either perfusion or immersion.

\section{Discussion}

The size of the capillary endothelial pores, fixation techniques and the nature of fixatives have been a subject of discussion. In his study of liver sinusoids using the thin section electron microscopy and freeze-etching method, WISSE (1970) claimed that the intracellular fenestrations larger than $0.1 \mu \mathrm{m}$ in diamter are artifacts due to an unsuitable fixation. On the contrary, Motta and Porter (1974), Muto (1975) and Muto et al. (1977) reported the presence of these larger fenestrations in their scanning electron microscopic studies, whereas OrCI et al. (1971), using the same methods as WISSE, also suggested the existence of large fenestrations.

The present study has clarified that the size and distribution of endothelial pores are not affected by the conditions of fixation, whether by perfusion or by immersion.

The endothelial pores of the liver sinusoids are highly variable in shape and size as compared with those of capillaries in other organs. These pores are classified into three types according to their size. Of these, the large type pores larger than $500 \mathrm{~nm}$ in diameter are exclusively found in this organ. It is thought that larger materials can easily pass through these pores characteristic of liver sinusoids.

The endothelial pores of the blood capillary of the thyroid gland correspond only to the small type of the liver. The same is the case in the endothelium of the anterior and posterior pituitary (unpublished data). The exchange of materials through the capillary endothelium in these endocrine organs is more limited as compared with the liver sinusoids.

The capillary endothelium of the adrenal gland is mid-way between the endothelium of the liver and that of the thyroid in size and shape of its pores. This finding suggests that the endothelium of this organ is unique in nature and function as compared with other endocrine glands. SHEL Ton and Jones (1971), who observed that the subendothelial space is narrow and numerous microvillous projections of the parenchymal cell protrude into this space in the mouse adrenal cortex, speculated that the exchange of materials between the cortical cell and the capillary blood is enhanced. The cortical hormones are known to be released into the blood violently and rash by a stress, and to be necessary for the methylation of noradrenaline to make adrenaline in the medullary cell (Wurtman and Axelrod, 1966). These might 
be related to the characteristic structure of the capillary endothelium of the adrenal gland. Further investigations are needed to answer this problem.

\section{マウス肝臓，甲状腺，副腎の毛細血管内皮の \\ 小孔のフリーズーエッチング像の観察}

\section{石 村 和 敬, 岡 本壽 男, 藤 田 向 男}

マウスの肝臓，甲状腺，副腎の毛細血管内皮のフリーズーエッチング像を観察したとこ ろ, 器官によって小孔（空）の大きさに差のあることがわかった.

肝臓の内皮の小孔は大きさが不揃いで， $50 \mathrm{~nm} \sim 1 \mu$ を示す. 小型（直径 $100 \mathrm{~nm}$ および それ以下のもの), 中型（直径 100-500 $\mathrm{nm}$ のもの), 大型 (500 $\mathrm{nm}$ 以上のもの) に分ける と，それぞれ $69.8 \% ， 27.6 \% ， 2.6 \%$ となる。

甲状腺では 小孔の大きさほ ほぼ一定で，小型のものしかなく，70-90nm 宗す.

副腎皮質および髄質では 70-400 nm を示し，小型と中型のみが認められる，皮質では 前者 $80.6 \%$ ，後者 $19.4 \%$ であつた.

このような, 器官による小孔の大きさの差は，毛細血管内腔と血管周囲腔の間の物質交 換の度合いと深い関係があると考えられる。

潅流固定，浸漬固定のいずれにおいても，所見に著しい变化は来さなかつた。

\section{References}

Friederici, H. H. R.: The tridimensional ultrastructure of fenestrated capillaries. J. Ultrastr. Res. 23: 444-456 (1968).

: On the diaphragm across fenestrae of capillary endothelium. J. Ultrastr. Res. 27: 373375 (1969).

Fujita, H., H. Mishima and N. Otsuka : Freeze-etching images of rabbit thyroid glands. Arch. histol. jap. 38: 275-284 (1975).

Ishimura, K., H. Okamoto and H. Fujita : Freeze-etching studies on ultrastructural changes of endothelial cells in the thyroid of normal, TSH-treated and Thyradin-treated mice. Cell Tiss. Res. 175: 313-317 (1976).

Maul, G. G.: Structure and formation of pores in fenestrated capillaries. J. Ultrastr. Res. 36: 768-772 (1971).

Motta, P. and K. R. Porter: Structure of rat liver sinusoid and associated tissue spaces as revealed by scanning electron microscopy. Cell Tiss. Res. 148: 111-125 (1974).

Muto, M: A scanning electron microscopic study on endothelial cells and Kupffer cells in rat liver sinusoids. Arch. histol. jap. 37: 369-386 (1975).

Muto, M., M. Nishi and T. Fujita: Scanning electron microscopy of human liver sinusoids. Arch. histol. jap. 40: 137-151 (1977).

Orci, L., A. Matter and Ch. Rouiller : A comparative study of freeze-etch replicas and thin sections of rat liver. J. Ultrastr. Res. 35: 1-19 (1971).

Shelton, J. H. and A. L. Jones: The fine structure of the mouse adrenal cortex and the ultra- 
structural changes in the zona glomerulosa with low and high sodium diet. Anat. Rec. 170: 147-182 (1971).

Simionescu, M., N. Simionescu and G. E. Palade: Morphometric data on the endothelium of blood capillaries. J. Cell Biol. 60: 128-152 (1974).

Smith, R. E. and M. G. Farquhar : Lysosome function in the regulation of the secretory process in cells of the anterior pituitary gland. J. Cell Biol. 31: 319-347 (1966).

Wisse, E.: An electron microscopic study of the fenestrated endothelial lining of rat liver sinusoids. J. Ultrastr. Res. 31: 125-150 (1970).

Wurtman, R. J. and J. Axelrod: Control of enzymatic synthesis of adrenaline in the adrenal medulla by adrenal cortical steroids. J. biol. Chem. 241: 2301-2305 (1966).

Yamamoto, K., S. Fujimoto and Y. Takeshige : The fine structure of endothelial cells in freezefracture preparations. J. Ultrastr. Res. 54: 22-28 (1976).

\author{
藤田尚男 \\ 于734 広島市霞 $1-2-3$ \\ 広島大学医学部 \\ 第二解剖学教室
}

Prof. Hisao Fujita

Department of Anatomy

Hiroshima University School of Medicine

Hiroshima, 734 Japan 